\title{
Spatial Distribution of Acidic Chitinases and Their Messenger RNAs in Tobacco Plants Infected with Cherry Leaf Roll Virus
}

\author{
J. M. Balsalobre, P. Más, M. A. Sánchez-Pina, and V. Pallás \\ Departamento de Mejora y Patología Vegetal CEBAS (CSIC) Avenida de la Fama 1, 30003 Murcia Spain \\ Received 6 February 1997. Accepted 13 May 1997.
}

\begin{abstract}
Cherry leaf roll virus (CLRV) infection in Nicotiana tabacum cv. Xanthi nc plants induces the expression of, among others, basic and acidic chitinases at 3 d.p.i. (days postinoculation) and 8 d.p.i. in inoculated and uninoculated, systemically infected leaves, respectively. The spatial distribution of the acidic tobacco chitinases (PR-P and PR-Q) mRNAs in CLRV-infected tobacco leaves has been studied by tissue printing and Northern (RNA) blot analysis. The mRNA was preferentially detected in and around the concentric necrotic rings caused by the viral infection. In addition, the accumulation pattern of the proteins was very similar although a basal signal was detected in nonsymptomatic tissue in uninoculated, systemically infected leaves. These results indicate a positive association of acidic chitinase gene expression with the necrotic tissue, where the virus is mainly localized, in the CLRV-tobacco interaction.
\end{abstract}

Plant susceptibility to viral infection is influenced by the ability of the plant to develop effective defense responses. In an incompatible interaction, the plant induces several local responses that prevent the viral invasion. This phenomenon is known as hypersensitive reaction (HR) and involves the rapid death of the first infected cells and the appearance of necrotic lesions that contribute to the limitation of the virus at the initial infection site. Concomitant with the HR, there is a transcriptional activation of plant genes encoding defense proteins, commonly referred to as pathogenesis-related (PR) proteins (Bol et al. 1990; Linthorst 1991; Ryals et al. 1992; Stintzi et al. 1993). This characteristic activation is not exclusive to the HR since generalized induction of defense responses also occurs in compatible interactions (Godiard et al. 1991; Jakobek and Lindgren 1993).

Based on both their serological properties and their primary structures, tobacco PR proteins have been classified into five principal groups. Among them, the PR-3 group consists of both acidic (PR-P and PR-Q) and basic (Chi-32, Chi-34, lys b1 and lys b2) chitinases (Linthorst 1991; Stintzi et al. 1993). Upon infection of tobacco leaves with tobacco mosaic virus

Corresponding author: V. Pallás; Fax: 34-68-26.66.13;

E-mail: vpallas@natura.cebas.csic.es

J. M. Balsalobre and P. Más contributed equally to this manuscript.
(TMV), there is a coordinated induction of the mRNAs for these acidic chitinases (Vogeli-Lange et al. 1988; Payne et al. 1990; Ward et al. 1991; Brederode et al. 1991). cDNA clones of the acidic chitinases PR-P and PR-Q have been obtained and their nucleotide sequence determined (Linthorst et al. 1990; Payne et al. 1990). PR-P and PR-Q are similar, exhibiting $93 \%$ identity, but differ significantly from the basic chitinases (57\% amino acid similarity) (Linthorst et al. 1990).

Although the spatial distribution of PR-P and PR-Q has been studied in virus-inoculated as well as in uninoculated upper leaves (Heitz et al. 1994), as far as we know no studies have been carried out with regard to the spatial distribution of their mRNA expression. Here, we investigate this distribution by tissue printing and Northern (RNA) blot analysis in tobacco plants systemically infected with cherry leaf roll virus (CLRV), and compare it with the accumulation pattern of the protein.

CLRV belongs to the group of nepoviruses consisting of two genomic RNAs (Jones 1985; Pallás et al. 1992). Although CLRV induces concentric necrotic rings in tobacco, the virus is able to overcome this defense mechanism to reach vascular tissue and systemically invade the plant, forming the same type of symptoms in upper leaves. In this sense, this interaction could be interpreted as an inefficient HR.

Plants of Nicotiana tabacum cv. Xanthi nc were inoculated with $10 \mathrm{ng} / \mathrm{ml}$ of the walnut isolate of CLRV by rubbing the leaves with Carborundum as abrasive. Protein samples (32 mg of fresh tissue) of mock-inoculated, inoculated, and uninoculated, systemically CLRV-infected tobacco leaves were extracted at different days postinoculation (d.p.i.) as described by Eggen et al. (1988). The samples were electrophoresed under denaturing conditions (Laemmli 1970) and the gels were stained for $20 \mathrm{~min}$ with $0.25 \%$ (wt/vol) Coomassie brilliant blue (R250, Sigma, St. Louis, MO) in aqueous methanol containing $10 \%$ acetic acid, and destained for $3 \mathrm{~h}$ in the same solution of methanol/acetic acid/water. After electrophoresis, the proteins were transferred overnight to Immun-Lite Blotting Membranes (BioRad Laboratories, Richmond, CA). For Western blot (immunoblot) analysis, anti-PR-Chi-32 and anti-PR-Q antibodies at 1:5,000 dilution (kindly provided by B. Fritig) (Legrand et al. 1987) were used. Blocking, first antibody incubation, conjugate binding, and blot development were performed according to the manufacturer (BioRad Laboratories).

To visualize the spatial distribution of the acidic chitinase protein, leaves were printed onto nitrocellulose membranes 
(No. BA85, Schleicher and Schuell, Keene, NH) as described previously by Más and Pallás (1995). Briefly, the upper surfaces of the leaves were printed on the membrane with a roller applying a uniform pressure and beginning from the tip of the leaf. After printing, the membranes were washed twice in PBS
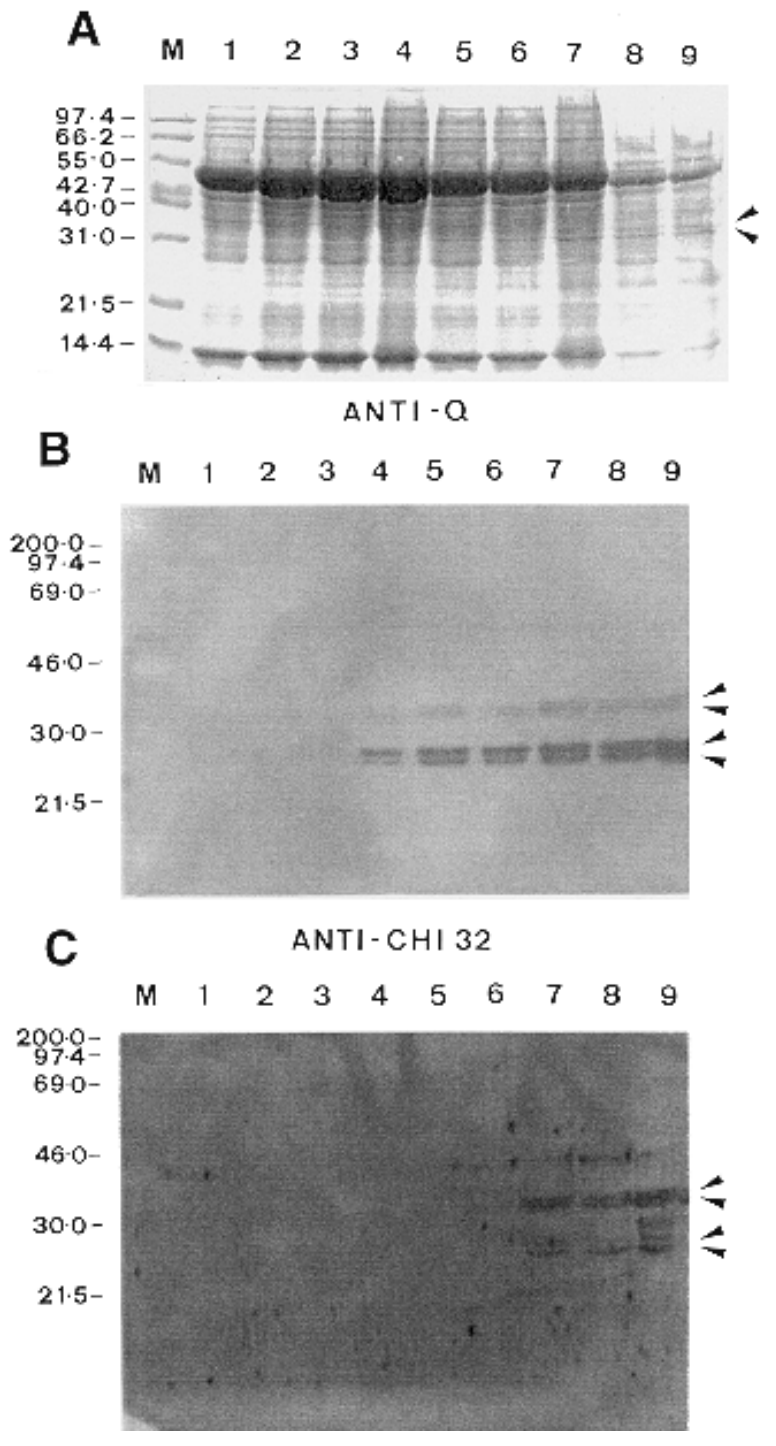

Fig. 1. Time-course analysis of acidic and basic tobacco chitinases after inoculation with cherry leaf roll virus (CLRV). A, Sodium dodecyl sulfate-polyacrylamide gel electrophoresis of total protein extracts corresponding to $32 \mathrm{mg}$ of fresh tissue from mock-inoculated (lane 1) or CLRV-inoculated leaves at $1,2,3,4,5,8,12$, and 15 days postinoculation (lanes 2 to 9). Size (in $\mathrm{kDa}$ ) of protein markers (M) is indicated along left margin. Proteins were stained with Coomassie blue. Arrowheads show the two main pathogenesis-related (PR) proteins inducible by CLRV infection. Duplicated gels were electrotransferred to ImmunLite membranes (Bio-Rad Lab., Richmond, CA) and blotted with a PR$\mathrm{Q}$ antibody (ANTI-Q in B) or a PR-Chi-32 antibody (ANTI-CHI-32 in C). Chemiluminescent substrate (AMPPD) was used to detect PR proteins; film was exposed for 20 to $30 \mathrm{~min}$. Arrowheads in (B and $\mathbf{C}$ ) show from top to bottom the two basic (Chi-34 and Chi-32) and two acidic (PR-Q and PR-P) tobacco chitinases.
(136 mM NaCl, $2.7 \mathrm{mM} \mathrm{KCl,} 10 \mathrm{mM} \mathrm{Na} 2 \mathrm{HPO}_{4}, 1.76 \mathrm{mM}$ $\mathrm{KH}_{2} \mathrm{PO}_{4}, \mathrm{pH} 7.4$ ) for $10 \mathrm{~min}$ and incubated in $3 \%$ bovine serum albumin (BSA) in PBS for $2 \mathrm{~h}$. Primary antibody against the acidic chitinase (PR-Q) was diluted 1:5,000 in 3\% BSA in PBS. The membranes were incubated in this antibody solution for $2 \mathrm{~h}$, and development of purple color was performed as previously described (Más and Pallás 1996).

The spatial distribution of the acidic chitinase mRNA was analyzed by Northern blot and tissue printing. Northern hybridization was performed with total RNA extracted from four areas of a systemically infected leaf that all had typical ringspot symptoms. Asymptomatic and healthy tissue of identical dimensions were also processed. The samples were cut with a 0.7-cm-diameter punch and total nucleic acids were extracted as described in Más and Pallás (1995). The samples were glyoxal denatured (McMaster and Carmichel 1977) and analyzed by electrophoresis in $N$-2-hydroxyethylpiperazine- $N N^{\prime}-2$ ethanesulfonic acid (HEPES) $20 \mathrm{mM} \mathrm{pH} \mathrm{7.} \mathrm{After} \mathrm{electropho-}$ resis, the gel was soaked in $50 \mathrm{mM} \mathrm{NaOH}$ for $15 \mathrm{~min}, 50 \mathrm{mM}$ sodium acetate/ acetic acid for an additional $15 \mathrm{~min}$, and then stained in ethidium bromide. The gel was transferred to a nylon membrane with $10 \times \mathrm{SSC}(1.5 \mathrm{M} \mathrm{NaCl}, 0.15 \mathrm{M}$ sodium citrate $\mathrm{pH}$ 7.00), according to standard procedures (Sambrook et al. 1989). Prehybridization, hybridization, and chemiluminescent detection were performed as described previously (Más et al. 1993). To quantify the levels of chitinase and viral RNA accumulation, the films were analyzed with a densitometer. A control $18 \mathrm{~S}$ rRNA probe was used to normalize the levels of RNA transferred in each blot.

Tissue print analysis of RNA was performed as described above except that the leaves were printed onto nylon membranes (Hybond, Boehringer Mannheim, Mannheim, Germany) and cross-linked with UV light for $3 \mathrm{~min}$. Prehybridization, hybridization, and chemiluminescent RNA detection were performed as described previously (Más and Pallás 1995). The DIG RNA labeling kit (Boehringer) was used for the synthesis of the probes and the transcription reactions were performed as recommended by the manufacturer. Three classes of digoxigenin-labeled RNA probes were synthesized. The acidic PR-P chitinase clone, Tach- 8 (kindly provided by H. J. M. Linthorst, Gorlaeus Laboratories-Leiden University) (Linthorst et al. 1990) was used to synthesize the chitinase

Table 1. Time-course analysis of the relationship between the viral signal, the appearance of the symptoms, and the acidic chitinase accumulation in cherry leaf roll virus-infected tobacco leaves

\begin{tabular}{lccccccc}
\hline \multirow{2}{*}{$\begin{array}{l}\text { Days post- } \\
\text { inoculation }\end{array}$} & \multicolumn{3}{c}{ Inoculated leaves } & & \multicolumn{3}{c}{ Systemically infected leaves } \\
\cline { 2 - 5 } \cline { 6 - 7 } & V.S. $^{\mathbf{a}}$ & Symptoms & Chitinase $^{\mathbf{b}}$ & V.S. & Symptoms & Chitinase \\
\hline 0 & - & - & - & - & - & - & - \\
1 & + & - & + & - & - & - & - \\
2 & + & + & + & - & - & - \\
3 & + & + & + & + & + & - & - \\
4 & + & + & + & + & + & + & - \\
5 & + & + & + & + & + & + \\
6 & + & + & + & + & + & + & + \\
8 & + & + & + & + & + & + & + \\
12 & + & + & + & + &
\end{tabular}

a Viral signal, determined by tissue printing or dot-blot hybridization.

${ }^{b}$ Acidic chitinase accumulation determined by Western blot (immunoblot) analysis. 
RNA probe. The ribosomal RNA probe was synthesized with the pR63 clone corresponding to the $18 \mathrm{~S}$ ribosomal RNA (rRNA) from radish (Olmedilla et al. 1993) that was kindly made available to us by A. Olmedilla (CSIC-Granada, Spain), who in turn obtained it from M. Delseny (CNRS-Perpignan,

\section{$\begin{array}{llllll}1 & 3 & 6 & 10 & 12 & M\end{array}$}

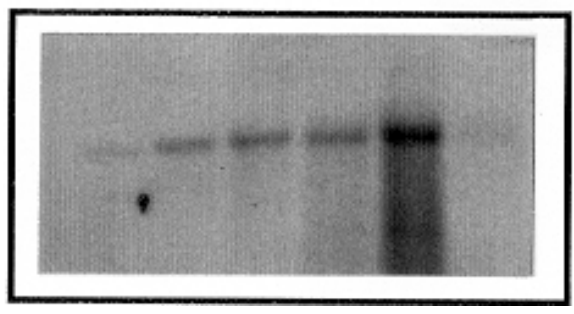

Fig. 2. Time course of acidic chitinase mRNA accumulation (in days) in inoculated leaves of cherry leaf roll virus-infected tobacco plants. Days postinoculation (d.p.i.) are shown above each lane. Lane $\mathrm{M}$ corresponds to a mock-inoculated plant analyzed at 6 d.p.i.. For mRNA analysis, total nucleic acids were extracted, glyoxilated, and electrophoressed on a $1 \%$ denaturing agarose gel. Northern (RNA) blots were probed with a digoxigenin-labeled chitinase mRNA and exposed for $2 \mathrm{~h}$.
France). Viral RNAs probe was synthesized as described in Más et al. (1993).

Protein extracts from CLRV-inoculated leaves at different d.p.i. were separated in sodium dodecyl sulfate-acrylamide gels and stained with Coomassie blue (Fig. 1A). Western analysis with an anti-PR-Q antibody showed two bands of $27 \mathrm{kDa}$ and $28 \mathrm{kDa}$, corresponding to acidic chitinases PR-P and PR-Q, respectively, that were detected at 3 d.p.i. (Fig 1B, lane 4); the amount of these proteins increased until 8 to 12 d.p.i. (Fig. 1B, lanes 7 to 9). In addition, two minor bands of $32 \mathrm{kDa}$ and 34 $\mathrm{kDa}$, corresponding to basic chitinases Chi-32 and Chi-34, were also observed (Fig. 1B). The PR-Q antibodies had previously been shown to cross-react with basic chitinases (see Table 1 in Heitz et al. [1994]). Analysis with the anti-Chi-32 antibody revealed a delay in the detection of the basic chitinases (Fig. 1C) because of the lower recognition capability of the antiserum. The same kind of analysis was carried out in uninoculated, systemically infected leaves processed at $3,4,5,8,12$, and 15 d.p.i. The results (not shown) revealed that acidic chitinases became evident at 8 d.p.i. This accumulation pattern of acidic chitinases in inoculated and upper uninoculated leaves ( 3 and 8 d.p.i., respectively) was delayed with regard to the pattern of viral RNA that was detected at 1 and 5 d.p.i., respectively (Table 1 and Más and Pallás 1996). This differential timing would be in agreement
A

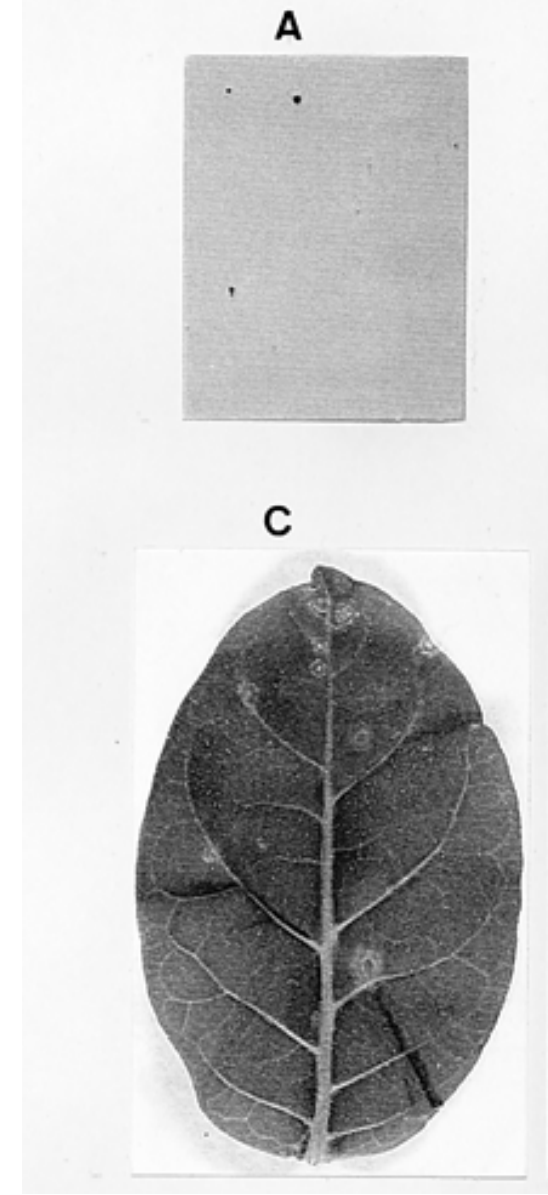

B

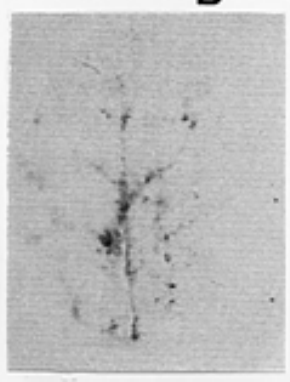

D

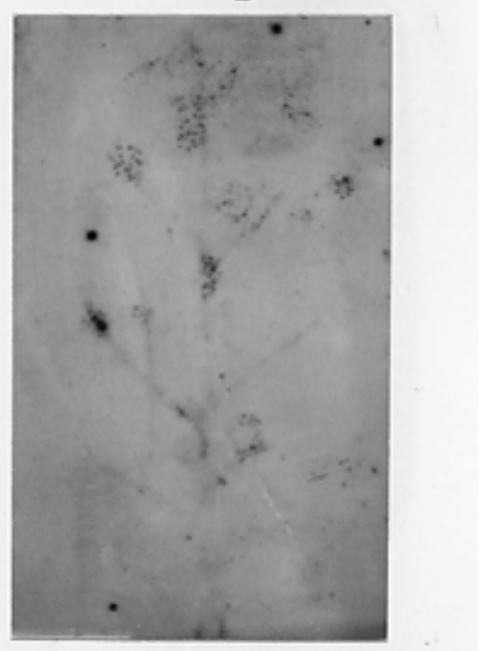

Fig. 3. Spatial distribution of the tobacco acidic chitinase mRNA in cherry leaf roll virus (CLRV)-infected leaves. A, Mock-inoculated, B, CLRV-inoculated. and $\mathbf{C}$ and $\mathbf{D}$, uninoculated, systemically CLRV-infected leaves were blotted to nylon membranes. Membranes (A, B, D) were probed against a chitinase digoxigenin-labeled RNA probe and exposed for $1 \mathrm{~h}$. 
with the idea that successful infection by a pathogen is likely to be caused by delayed plant defense expression rather than by any absence or inactivation of defense mechanisms (Dixon et al. 1994). Time course analysis of the acidic chitinase mRNA in inoculated tobacco leaves revealed that the mRNA accumulates to detectable levels at 3 d.p.i. and increases until 10 to 12 d.p.i. (Fig. 2), similar to the induction pattern observed for the proteins (Fig. 1).

The spatial distribution of the acidic chitinase protein and its mRNA was studied by the tissue printing technique (Fig. 3) and Northern and Western blot analysis (Fig. 4). Inoculated and uninoculated, systemically infected tobacco leaves were processed at 12 and 15 d.p.i., respectively. In inoculated

\section{RNA}

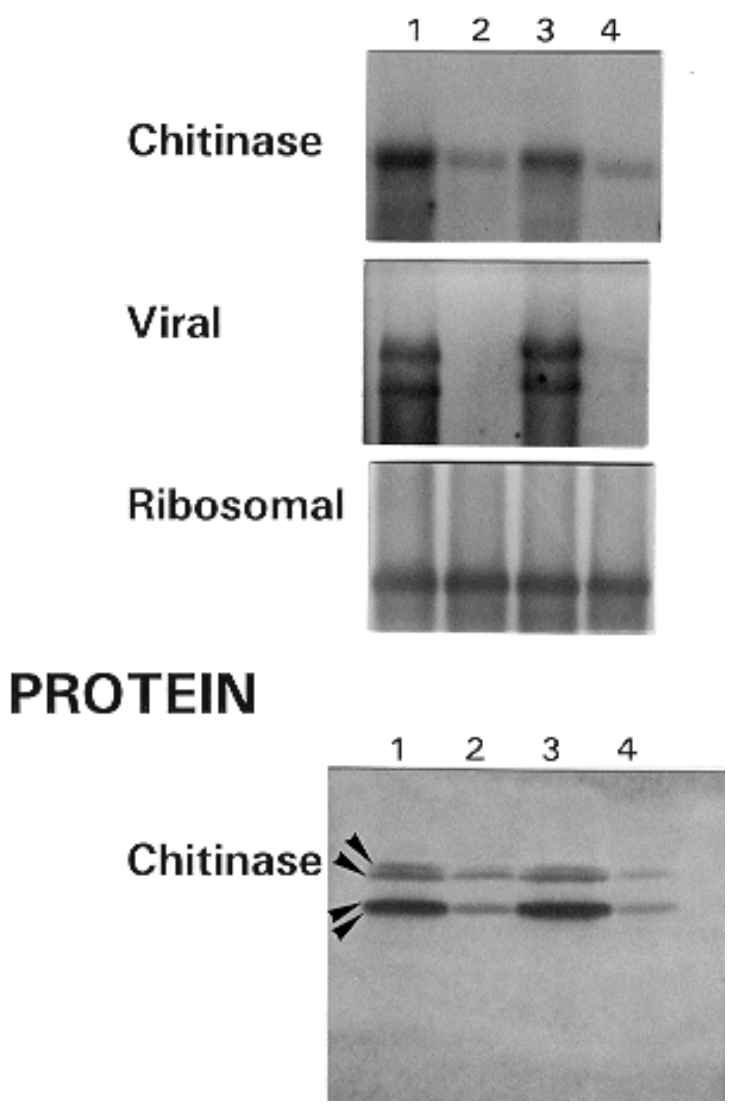

Fig. 4. Analysis of tobacco acidic chitinase PR-Q (Protein) and its mRNA (RNA) after inoculation with cherry leaf roll virus (CLRV). For mRNA analysis, total nucleic acids were extracted, glyoxilated, and electrophoressed on a $1 \%$ denaturing agarose gel. Northern (RNA) blots were carried out with digoxigenin-labeled probes to detect chitinase mRNA, viral RNA, or ribosomal RNA. Films were exposed either for $2 \mathrm{~h}$ (chitinases) or 20 min (viral and ribosomal RNAs). For PR-Q detection, similar samples were extracted for total protein and analyzed by Western blot (immunoblot) with a 1:5,000 dilution of the anti-PR-Q antibody. Film was exposed for $30 \mathrm{~min}$. Lanes 1 and 2: symptomatic and asymptomatic areas of uninoculated, systemically infected leaves. Lane 3: CLRV-inoculated leaves. Lane 4: mockinoculated leaves. In lanes 3 and 4, samples were harvested at 12 days postinoculation (d.p.i.); in lanes 1 and 2, at 15 d.p.i.. Arrowheads show from top to bottom the two basic (Chi-34 and Chi-32) and two acidic (PR-Q and PR-P) tobacco chitinases that, unlike the gels shown in Figure 1 , are resolved as almost single bands. leaves, the chitinase mRNA appeared associated with the viral infection foci that were distributed throughout the leaf (Fig. 3B). No signal was observed in control mock-inoculated leaves (Fig 3A). In uninoculated, systemically infected leaves, the virus induces concentric necrotic rings preferentially associated with the vein network (Fig. 3C). The hybridization signal of the chitinase mRNA closely corresponds to the area surrounding necrotic ringspot, as can be observed in Figure 3D. In the case of the experiment presented in Figure 3D, a very strong signal can be observed in the middle part of the main vein. This signal corresponds to a typical symptom that appeared over the vein and cannot be considered a proper signal coming from the vascular tissue. However, less intense signals were also observed in the veins while there was no signal in asymptomatic areas. The reliability of the tissue-printing results was confirmed by the signal obtained when the membrane was hybridized with the ribosomal RNA probe. In this case, the signal appeared distributed throughout the leaf (data not shown). With Northern blot analysis, similar results were found with the hypersensitive TMV-tobacco system, in which the PR-1 mRNA was strongly expressed in the area surrounding necrotic lesions (Friedrich et al. 1995). Northern blot analysis was performed to quantify the accumulation pattern of the chitinase mRNA in infected leaves. Inoculated leaves and four areas affected by typical ringspot symptoms of uninoculated, systemically infected leaves were sampled at 12 and 15 d.p.i., respectively, and total RNA was extracted. Similar size areas of asymptomatic zones and mock-inoculated tissue were identically processed. The RNA blots were hybridized with the probes specific for the chitinase mRNA (Fig. 4, RNA, chitinase), viral genomic RNAs (Fig. 4, RNA, viral) and 18s ribosomal RNA (Fig. 4, RNA, ribosomal). The results showed that the levels of chitinase mRNA were 2.5 times higher in symptomatic areas (lane 1) and inoculated leaves (lane 3) than in asymptomatic (lane 2) and control mock-inoculated leaves (lane 4). This chitinase mRNA induction was clearly associated with the viral RNA accumulation (compare Figure 4, Chitinase and Viral). In all the extractions the levels of rRNA were similar (Fig. 4, Ribosomal).

The tissue-printing technique was also used to visualize the spatial distribution of the acidic chitinase protein PR-Q in CLRV-infected tobacco leaves (data not shown). In this case, Western blot analysis, a more sensitive technique than immuno-printing, was needed to get conclusive results about protein distribution (Fig. 4, Protein). Protein extracts corresponding to the inoculated and mock-inoculated leaves were processed at 12 d.p.i. (lanes 3 and 4) while symptomatic and asymptomatic areas of uninoculated, systemically infected leaves were processed at 15 d.p.i. (lanes 1 and 2). The densitometer analysis showed that in symptomatic areas (Fig. 4, Protein, lane 1) there was a 2.5-fold increase in PR concentration, compared with that observed in asymptomatic zones (Fig. 4, Protein, lane 2). The densitometer values obtained were normalized to the levels of PR protein in control mockinoculated leaf.

Previous results have demonstrated that PR-1 induced by TMV in N. tabacum cv. Xanthi nc plants accumulates in the tissue surrounding the lesions (Antoniw and White 1986). More recently, Heitz et al. (1994), using Western blot analysis, extended the study to four serological groups of PR proteins. The relative induction of the different proteins was found to 
be highly variable and the highest induction in all the PR proteins was restricted to a number of cells surrounding the lesions. In this work, we present evidence by tissue-printing technique for the spatial distribution of the mRNA of the acidic chitinases. The preferential accumulation of the mRNA around the concentric necrotic rings is in agreement with those previous results regarding the protein accumulation pattern. The signal observed in asymptomatic areas of uninoculated, systemically infected leaves in the Northern blot experiments could be due to the basal expression of the mRNAs, as observed in mock-inoculated plants. Brederode et al. (1991) and Ward et al. (1991) have shown that, unlike the genes for basic PR proteins, most genes for acidic PR proteins are systemically induced in the uninfected upper leaves of TMV-infected plants. The detection of acidic chitinase in asymptomatic areas in secondary infected tissue could also be explained by this phenomenon. Finally, since the ratio of mRNA and protein in symptomatic versus asymptomatic tissue is the same (2.5-fold increase), the increase in the level of accumulation of the protein associated with symptomatic areas could be explained by the increase in the level of accumulation of its mRNA.

\section{ACKNOWLEDGMENTS}

We are grateful to H. J. M. Linthorst and B. Fritig for providing us with the Tach- 8 clone and the PR-Q and PR-Chi-32 antisera, respectively. We also acknowledge H. J. M. Linthorst, P. Vera, and J. F. Marcos for critical reading of the manuscript. This work was supported in part by grants PB91-0058 and BIO96-0459 from the Spanish granting agency DGYCIT. P.M. is the recipient of a fellowship from the Consejeria de Cultura y Educación de la Región de Murcia.

\section{LITERATURE CITED}

Antoniw, J. F., and White, R. F. 1986. Changes with time in the distribution of virus and PR protein around single local lesions of TMV infected tobacco. Plant Mol. Biol. 6:145-149.

Bol, J. F., Linthorst, H. J. M., and Cornelissen, B. J. C. 1990. Plant pathogenesis-related proteins induced by virus infection. Annu. Rev. Phytopathol. 28:113-138.

Brederode, F. T., Linthorst, H. J. M., and Bol, J. F. 1991. Differential induction of acquired resistance and PR gene expression in tobacco by virus infection, ethephon treatment, UV light and wounding. Plant Mol. Biol. 17:1117-1125.

Dixon, R. A., Harrison, M. J., and Lamb, C. J. 1994. Early events in the activation of plant defense responses. Annu. Rev. Phytopathol. 32: 479-501.

Eggen, R., Kaan, A., Goldbach, R., and van Kammen, A. 1988. Cowpea mosaic virus RNA replication in crude membrane fractions from infected cowpea and Chenopodium amaranticolor. J. Gen. Virol. 69: 2711-2720.

Friedrich, L., Vernooij, B., Gaffney, T., Morse, A., and Ryals, J. 1995. Characterization of tobacco plants expressing a bacterial salicylate hydroxylase gene. Plant Mol. Biol. 29:959-968.

Godiard, L., Froissard, D., Fournier, J., Axelos, M., and Marco, Y. 1991. Differential regulation in tobacco cell suspensions of genes involved in plant-bacteria interactions by pathogen-related signals. Plant Mol. Biol. 17:409-413.
Heitz, T., Fritig, B., and Legrand, M. 1994. Local and systemic accumulation of pathogenesis-related proteins in tobacco plants infected with tobacco mosaic virus. Mol. Plant-Microbe Interact. 7:776-779.

Jakobek, J. L., and Lindgren, P. B. 1993. Generalized induction of defense responses in bean is not correlated with the induction of the hypersensitive reaction. Plant Cell 5:49-56.

Jones, A. T. 1985. Cherry leaf roll virus. No. 306 in: Descriptions of Plant Viruses. Commonw. Mycol. Inst./Assoc. Appl. Biol., Kew, England.

Laemmli, U. K. 1970. Cleavage of structural proteins during the assembly of the head of bacteriophage T4. Nature (London) 227:680-685.

Legrand, M., Kauffmann, S., Geoffroy, P., and Fritig, B. 1987. Biological function of pathogenesis-related proteins: Four tobacco pathogenesis-related proteins are chitinases. Proc. Natl. Acad. Sci. USA 84: 6750-6754.

Linthorst, H. J. M. 1991. Pathogenesis-related proteins of plants. Crit. Rev. Plant Sci. 10:123-150.

Linthorst, H. J. M., van Loon, L. C., van Rossum, C. M. A., Mayer, A., Bol, J. F., van Roekel, J. S. C., Meulenhoff, E. J. S., and Cornelissen, B. J. C. 1990. Analysis of acidic and basic chitinases from tobacco and petunia and their constitutive expression in transgenic tobacco. Mol. Plant-Microbe Interact. 3:252-258.

Más, P., and Pallás, V. 1995. Non-isotopic tissue-printing hybridization: A new technique to study long-distance plant virus movement. J. Virol. Methods 52:317-326.

Más, P., and Pallás, V. 1996. Long-distance movement of cherry leaf roll virus in infected tobacco plants. J. Gen. Virol. 77:531-540.

Más, P., Sánchez-Navarro, J. A., Sánchez-Pina, M. A., and Pallás, V. 1993. Chemiluminescent and colorigenic detection of cherry leaf roll virus with digoxigenin-labeled RNA probes. J. Virol. Methods 45:93-102.

McMaster, G. K., and Carmichel, G. G. 1977. Analysis of single-and double-stranded nucleic acids on polyacrylamide and agarose gels by using glyoxal and acridine orange. Proc. Natl. Acad. Sci. USA 74: 4835-4838.

Olmedilla, A., Testillano, P. S., Vicente, O., Delseny, M., and Risueño, M. C. 1993. Ultrastructural rRNA localization in plant cell nucleoli. RNA/RNA in situ hybridization, autoradiography and cytochemistry. J. Cell Sci. 106:1333-1346.

Pallás, V., Rowhani, A., Daubert, S., and Bruening, G. 1992. Properties and translation studies of cherry leaf roll virus (CLRV). Acta Hortic. 309:45-53.

Payne, G., Ahl, P., Moyer, M., Harper, A., Beck, J., Meins, F., and Ryals, J. 1990. Isolation of complementary DNA clones encoding pathogenesis-related proteins $\mathrm{P}$ and $\mathrm{Q}$, two acidic chitinases from tobacco. Proc. Natl. Acad. Sci. USA 87:98-102.

Ryals, J., Ward, E., and Métraux, J. P. 1992. Systemic acquired resistance: An inducible defense mechanism in plants. Pages 205-229 in: The Biochemistry and Molecular Biology of Inducible Enzymes and Proteins in Higher Plants. J. L. Wray, ed. Cambridge University Press, Cambridge, England.

Sambrook, J., Fritsch, E. F., and Maniatis, T. A. 1989. Molecular Cloning: A Laboratory Manual. 2nd ed. Cold Spring Harbor Laboratory, Cold Spring Harbor, NY.

Stintzi, A., Heitz, T., Prasad, V., Wiedemann-Merdinoglu, S., Kauffmann, S., Geoffroy, P., Legrand, M., and Fritig, B. 1993. Plant "pathogenesis-related" proteins and their role in defense against pathogens. Biochimie 75:687-706.

Vögeli-Lange, R., Hansen-Gehri, A., Boller, T., and Meins, F. 1988. Induction of the defense-related glucanohydrolases, $\beta$-1,3-glucanase and chitinase, by tobacco mosaic virus infection of tobacco leaves. Plant Sci. 54:171-176.

Ward, E. R., Ukness, S. J., Williams, S. C., Dincher, S. S., Wiederhold, D. L., Alexander, D. C., Ahl-Goy, P., Métraux, J. P., and Ryals, J. A. 1991. Coordinate gene activity in response to agents that induce systemic acquired resistance. Plant Cell 3:1085-1094. 